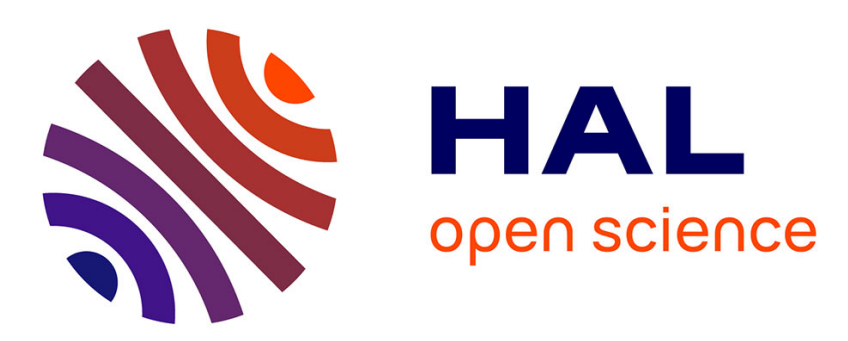

\title{
Influence of water vapour on the zircaloy-4 oxidation at high temperature - Stress determination by in situ X-Ray diffraction
}

\author{
Henri Buscail, Raphaël Rolland, Christophe Issartel
}

\section{- To cite this version:}

Henri Buscail, Raphaël Rolland, Christophe Issartel. Influence of water vapour on the zircaloy-4 oxidation at high temperature - Stress determination by in situ X-Ray diffraction. Annales de Chimie - Science des Matériaux, 2015, 39 (3-4), pp.115-122. 10.3166/acsm.39.115-122 . hal-01628252

\section{HAL Id: hal-01628252 \\ https://hal.uca.fr/hal-01628252}

Submitted on 3 Nov 2017

HAL is a multi-disciplinary open access archive for the deposit and dissemination of scientific research documents, whether they are published or not. The documents may come from teaching and research institutions in France or abroad, or from public or private research centers.
L'archive ouverte pluridisciplinaire HAL, est destinée au dépôt et à la diffusion de documents scientifiques de niveau recherche, publiés ou non, émanant des établissements d'enseignement et de recherche français ou étrangers, des laboratoires publics ou privés. 


\title{
INFLUENCE OF WATER VAPOUR ON THE ZIRCALOY-4 OXIDATION AT HIGH TEMPERATURE - STRESS DETERMINATION BY IN SITU X-RAY DIFFRACTION
}

\author{
Henri BUSCAIL ${ }^{\mathrm{a}}$, Raphaël ROLLAND ${ }^{\mathrm{a}}$, Christophe ISSARTEL ${ }^{\mathrm{a}}$ \\ ${ }^{a}$ Université de Clermont Auvergne, LVEEM, Laboratoire Vellave sur l'Elaboration et l'Etude des Matériaux, \\ 8 rue J.B. Fabre, CS 10219, 43009 Le Puy-en-Velay, France.
}

\begin{abstract}
A key parameter for the understanding the effect of water vapour on the oxidation mechanism is the determination of the stress level in the monoclinic zirconia scale and in the Zircaloy4 (Zy-4) substrate at high temperature. In order to provide an accurate description of the microstructure of the oxide layers, X-ray diffraction (XRD) analyses have been performed in situ under dry and wet oxidizing environments at high temperature on $\mathrm{Zy}-4$ flat sheet samples. The aim of the present work is to show the influence of water vapour on the stress developed at high temperature in the oxide scale as well as inside the alloy. The stress evolution during cooling to room temperature has also been determined.
\end{abstract}

Résumé -Le niveau de contrainte généré au sein de la couche de zircone monoclinique sur le Zircaloy4 (Zy-4) à haute température est un paramètre clé de la compréhension de l'effet de la vapeur d'eau sur le mécanisme d'oxydation mis en jeu. Afin de donner une description précise de la microstructure des couches d'oxyde nous avons utilisé la diffraction des rayons X (DRX) in situ sous air sec et sous air humide sur des échantillons plans de Zy-4 à haute température. Le but de ce travail est de déterminer l'influence de la vapeur d'eau sur les contraintes de croissance dans la couche de zircone monoclinique ainsi que dans le substrat métallique. Nous avons aussi étudié l'évolution des contraintes au cours du refroidissement.

\section{INTRODUCTION}

Increased attention has been paid to the vulnerability of the Spent Fuel Pools (SFPs) since the Fukushima accident. This vulnerability is of major concern for nuclear safety because SFPs which are large water-filled structures are generally placed outside the reactor containment building so that the fuel clad is the only barrier against fission product release in case of dewatering. To gain knowledge in the above mentioned areas and in order to better evaluate the safety margins, the French Institut de Radioprotection et de Sûreté Nucléaire (IRSN) in collaboration with partners from French universities has launched the experimental DENOPI project. Most of the kinetic investigations on the Zr-based 
cladding material oxidation in air at high temperature have used bare cladding samples. As far as spent fuels are concerned, the presence of corrosion oxide scale formed during normal operation in reactor has to be considered. In steam atmosphere a protective effect of the pre-oxide is generally observed. Zirconium alloys oxidation resistance is an important factor affecting their use as fuel cladding material in nuclear plants. It is generally accepted that during zirconium alloys oxidation, a dense and protective oxide layer first forms on the metal, giving rise to a reaction rate decreasing with time with a parabolic law $[1,2]$. However, after a certain time, a kinetic acceleration appears, corresponding to the breakaway phenomenon. This is related to the loss of protectiveness of the first formed oxide scale. Breakaway can occur several times, leading to corrosion kinetics showing a cyclic behaviour [1,2]. Post-transition phenomena are also encountered at temperatures expected in accidental situations, either in steam $[3,4]$ or oxygen and air atmospheres $[5,6]$. The oxidation resistance of a zircaloy, in usual operation conditions as well as in accidental situations, is controlled by the resistance to breakaway of the zirconia scale. The protectiveness loss is attributed to formation of diffusion shortcuts, for example micro-cracks, which were evidenced both for temperatures relevant to in-service conditions [5] and to accidental situations [6]. The breakaway phenomenon can be explained by mechanical considerations [7], but the transition is a complex phenomenon involving coupled chemical, mechanical, microstructural, crystallographic aspects. It has been mentioned that the transition from a protective to a more porous oxide could be associated to a phase transitions from tetragonal $\left(\mathrm{t}-\mathrm{ZrO}_{2}\right)$ to monoclinic $\left(\mathrm{m}-\mathrm{ZrO}_{2}\right)$, close to the metal/oxide interface [8]. From the literature, it has been experimentally demonstrated by X-ray diffraction (XRD) [9-13], Raman spectroscopy [14-17] or transmission electron microscopy $[18,19]$ that $\mathrm{t}-\mathrm{ZrO}_{2}$ can be detected at the metal/oxide interface in pre-transition scales while it is hardly detected in the scale during the post-transition regime. Various factors such as a deviation from stoichiometry, nanometric grain size, chemical doping, and compressive stresses can explain the stabilization of the $\mathrm{t}-\mathrm{ZrO}_{2}$ for temperatures below its thermodynamic stability domain. A high amount of $\mathrm{t}-\mathrm{ZrO}_{2}$ at the metal/oxide interface is often correlated with the presence of high local compressive stresses $[10,12,14,15,17]$. It has been confirmed by thermodynamic calculations that compressive stresses can stabilize the $\mathrm{t}-\mathrm{ZrO}_{2}$ form of zirconia [20], due to the high Pilling- Bedworth ratio of the $\mathrm{Zr} / \mathrm{ZrO}_{2}$ system. It is generally observed that zirconia scales exhibiting the highest compressive stresses and thus a better stability of the $\mathrm{t}-\mathrm{ZrO}_{2}$ compound exhibit a better corrosion resistance $[10-12,18]$. Most of the authors consider that the $\mathrm{t}-\mathrm{ZrO}_{2}$ to $\mathrm{m}-\mathrm{ZrO}_{2}$ transformation have a detrimental effect on the corrosion resistance. Nevertheless, El Kadiri and co-workers [16] suggest that this phase transformation has a beneficial effect. It is due to the lattice expansion that accompanies the transformation and it contributes to maintain a compressive stress state in the scale and thus delays the oxide breakdown, which occurs when the stress sign change from compressive to tensile firstly close to the external interface. Whatever is the exact role of the $\mathrm{t}-\mathrm{ZrO}_{2}$ to $\mathrm{m}-\mathrm{ZrO}_{2}$ transformation on the breakaway phenomenon, the local stress field that develops in oxide scales formed on $\mathrm{Zr}$ alloys appears to be an important factor for the understanding of their oxidation resistance. This explains why stress development in zirconia scales has been studied in the past. In case of loss of primary coolant accident in a light water reactor, the zirconium alloys fuel cladding would be oxidized in air and steam mixtures at high temperatures. From the recent literature review of Guerain and co-workers [21] it appears that no growth stress determinations have been performed on Zircaloy-4 (Zy-4) in dry air or in air/steam gas mixtures close to operating conditions at $500^{\circ} \mathrm{C}$. The key parameter for the understanding the effect of water vapour on the oxidation mechanism is the determination of the stress level in the zirconia scale and in the Zy-4 substrate at high temperature. In order to determine the structure and microstructure of the oxide layers, X-ray diffraction (XRD) analyses have been performed in situ under dry air and wet air environments at $500^{\circ} \mathrm{C}$ on $\mathrm{Zy}-4$ flat sheet samples. This temperature has been chosen in order to be 
close to the operation conditions in nuclear power plants. The aim of the present work is to show the influence of water vapour on the growth stresses developed at high temperature in the oxide scale as well as inside the alloy. The stress evolution during cooling to room temperature will also be determined in order to collect data on the influence of water vapour on the stress relaxation mechanism.

\section{EXPERIMENTAL}

The material used in the present work is a low tin Zircaloy-4 (Zy-4) alloy. The alloy composition is given in Table 1. The specimens, were cut by electro-erosion from a SRA (stress relieved annealed at $480^{\circ} \mathrm{C}$ ) flat sheet.

Table 1: Composition of the alloy used for stress determination.

\begin{tabular}{|l|l|l|l|l|l|l|l|l|}
\hline Alloy & \multicolumn{4}{|l}{ Composition $(\mathbf{w t} \%)$} & ppm & ppm & ppm \\
\hline & Zr & Sn & Fe & Cr & O & C & Nb & H \\
\hline Zy-4 & Balance & 1.32 & 0.21 & 0.11 & 0.12 & 125 & $<40$ & $<3$ \\
\hline
\end{tabular}

Flat specimens are $0.43 \mathrm{~mm}$ thick and show a total surface area of about $2.6 \mathrm{~cm}^{2}$. The in situ characterization of the oxide scales was carried out in a MRi high temperature chamber adapted on an Xpert'3 PANalytical $\Theta-\Theta$ Bragg- Brentano diffractometer (cobalt radiation, $\lambda_{k_{\alpha}}=0.179 \mathrm{~nm}$ ). The diffraction patterns are registered for five days $(120 \mathrm{~h})$ at $500^{\circ} \mathrm{C}$ and at $400,300,200,100$ and $20^{\circ} \mathrm{C}$ during cooling to room temperature. Each stress determination on the alloy or on the oxide scale takes about 5 hours. One should take care that for the 40 first hours oxidation in wet air the scale thickness is too low to permit a correct stress determination (the oxide peak intensity is two low). Then, no values are reported on the graphs concerning the growth stress in the oxide during this period. Concerning stress determination in the alloy, as long as the oxide scale is thin enough, the stress determination remains possible, which is the case at $500^{\circ} \mathrm{C}$ after 5 days. The water vapour experiments were performed in air containing $15 \mathrm{vol} . \% \mathrm{H}_{2} \mathrm{O}$. The laboratory compressed flowing air $(8 \mathrm{~L} / \mathrm{h}$ flow rate) is saturated through boiling water. Then, the water bath humidifier maintained at $55{ }^{\circ} \mathrm{C}$ controls the water vapour ratio by condensation of the excess water vapour. All the connecting tubes are maintained over $65^{\circ} \mathrm{C}$ in order to avoid any water condensation. A schematic drawing of the rig was provided in a previous paper [22]. Dry air testing was performed in flowing air at atmospheric pressure. Calibration of the sample temperature was performed with the help of a thermocouple welded on a Zy-4 specimen and placed on the heating element in the high temperature chamber.

Stress levels in $\mathrm{m}-\mathrm{ZrO}_{2}$ (ICDD 37-1484) were determined by in situ X-ray diffraction at $500{ }^{\circ} \mathrm{C}$ under atmospheric pressure conditions. Stress determinations were made by using $\psi$ goniometer technique, $[23,24]$ with $\mathrm{Co}-\mathrm{K}_{\alpha \mathrm{l}}=0.179 \mathrm{~nm}$ radiation, based on the (10-4) planes of the monoclinic $\mathrm{m}$ $\mathrm{ZrO}_{2}$ structure $\left(84.62^{\circ} 2 \Theta\right)$. No stress determination is possible on tetragonal zirconia with this technique. The $\psi$ angle was varied in steps of $2^{\circ}$ between $-38^{\circ}$ and $+38^{\circ}$. The mean stress $\sigma_{\phi}$ in the plane of the oxide is obtained from the slope $(1+v) . \sigma_{\phi} / \mathrm{E}$ of the linear relationship between $\varepsilon$ and $\sin ^{2} \psi$, where $\varepsilon$ is the strain, given by $\Delta \mathrm{d} / \mathrm{d}$, $\mathrm{d}$ being the interplanar spacing. The oxide was assumed to be isotropic with no stress gradients parallel to the surface components. The $\mathrm{m}-\mathrm{ZrO}_{2}$ Young's modulus, E, was taken as $203 \mathrm{GPa}$ at room temperature $\left(174 \mathrm{GPa}\right.$ at $\left.500^{\circ} \mathrm{C}\right)$ [25] and Poisson's ratio $v$ as 0.32 . The technique used is not able to determine the eventual stress gradient inside the oxide scale. Only a 
mean value is obtained from the whole surface and thickness analyzed. Stress determination in the metal is based on the (105) planes of the hexagonal $\mathrm{Zr}$ structure $\left(135.6^{\circ} 2 \Theta-\mathrm{Co}-\mathrm{K}_{\mathrm{\alpha l}}\right)$ (ICDD 65-3366). The $\psi$ angle was varied in steps of $2^{\circ}$ between $-45^{\circ}$ and $+45^{\circ}$. The mean stress $\sigma_{\phi}$ in the plane of the oxide is obtained from the slope $(1+v) \sigma_{\phi} / E$ of the linear relationship between $\varepsilon$ and $\sin ^{2} \psi$, where $\varepsilon$ is the strain, given by $\Delta \mathrm{d} / \mathrm{d}, \mathrm{d}$ being the interplanar spacing. The $\mathrm{Zy}-4$ alloy was assumed to be isotropic with no stress gradients parallel to the surface components. Zy-4 Young's modulus, E, was taken as 96 $\mathrm{GPa}$ at $500^{\circ} \mathrm{C}$ and Poisson's ratio $v$ as 0.33 . At $500^{\circ} \mathrm{C}$ and even after 120 hours oxidation, the oxide scale is thin enough to permit the alloy analysis. On the specimen exposed to dry air, the oxide scale is about $6 \mu \mathrm{m}$ thick and the analysed depth in zirconia is about $10 \mu \mathrm{m}$ which permits to analyse the underlying $\mathrm{Zy}-4$ all along the test.

\section{RESULTS}

3.1. Determination of the stress evolution in the $\mathrm{Zy}-4$ at $500{ }^{\circ} \mathrm{C}$ and during cooling to room temperature in dry air.

In situ growth stress determination has been performed on a $\mathrm{Zy}-4$ specimen in dry air at $500{ }^{\circ} \mathrm{C}$ for 5 days (120 hours). It appears that in dry air at $500{ }^{\circ} \mathrm{C}$ the stress in the $\mathrm{Zy}-4$ alloy is very low (-20 $+/-20 \mathrm{MPa}$ ) and does not vary for the $120 \mathrm{~h}$ oxidation test. During cooling the stress remains the same.

3.2. Determination of the stress evolution in the $\mathrm{m}-\mathrm{ZrO}_{2}$ oxide scale at $500{ }^{\circ} \mathrm{C}$ and during cooling to room temperature in dry air.

Figure 1 shows the in situ growth stress determination in the $\mathrm{m}-\mathrm{ZrO}_{2}$ on a $\mathrm{Zy}-4$ specimen in dry air at $500{ }^{\circ} \mathrm{C}$ for 5 days (120 hours). Before 20 hours oxidation, stress determinations where only performed in the alloy because the scale is not thick enough to collect valuable data concerning the $\mathrm{m}$ $\mathrm{ZrO}_{2}$ stress state. As soon as the determination is possible in the $\mathrm{m}-\mathrm{ZrO}_{2}$ scale, the compressive growth stress registered is relatively high $(-1800+/-200 \mathrm{MPa})$. It remains constant all along the oxidation test. At $300{ }^{\circ} \mathrm{C}$ and at lower temperatures the compressive stress decreased to reach $-850+/-200 \mathrm{MPa}$. The stress decrease indicates that a relaxation process occurred during cooling. On the specimen face exposed to dry air, the oxide scale is about $6 \mu \mathrm{m}$ thick.

3.3. Determination of the stress evolution in the $\mathrm{Zy}-4$ at $500{ }^{\circ} \mathrm{C}$ and during cooling to room temperature in wet air (15 vol. $\left.\% \mathrm{H}_{2} \mathrm{O}\right)$.

In situ growth stress determination has been performed on a $\mathrm{Zy}-4$ specimen in flowing wet air (15 vol.\% $\mathrm{H}_{2} \mathrm{O}$ ) at $500{ }^{\circ} \mathrm{C}$ and for 5 days (120 hours). For the 40 first hours oxidation, stress determinations where only performed on the alloy because the scale is not thick enough to collect data concerning the $\mathrm{m}-\mathrm{ZrO}_{2}$ stress state. In wet air, results show that at $500{ }^{\circ} \mathrm{C}$ the stress in the $\mathrm{Zy}-4$ alloy remains very low $(30+/-20 \mathrm{MPa})$ and does not vary for the $120 \mathrm{~h}$ oxidation test. No stress variation is registered during cooling from $500{ }^{\circ} \mathrm{C}$ to room temperature. The metallic behaviour is similar in dry and wet air during cooling to room temperature. 


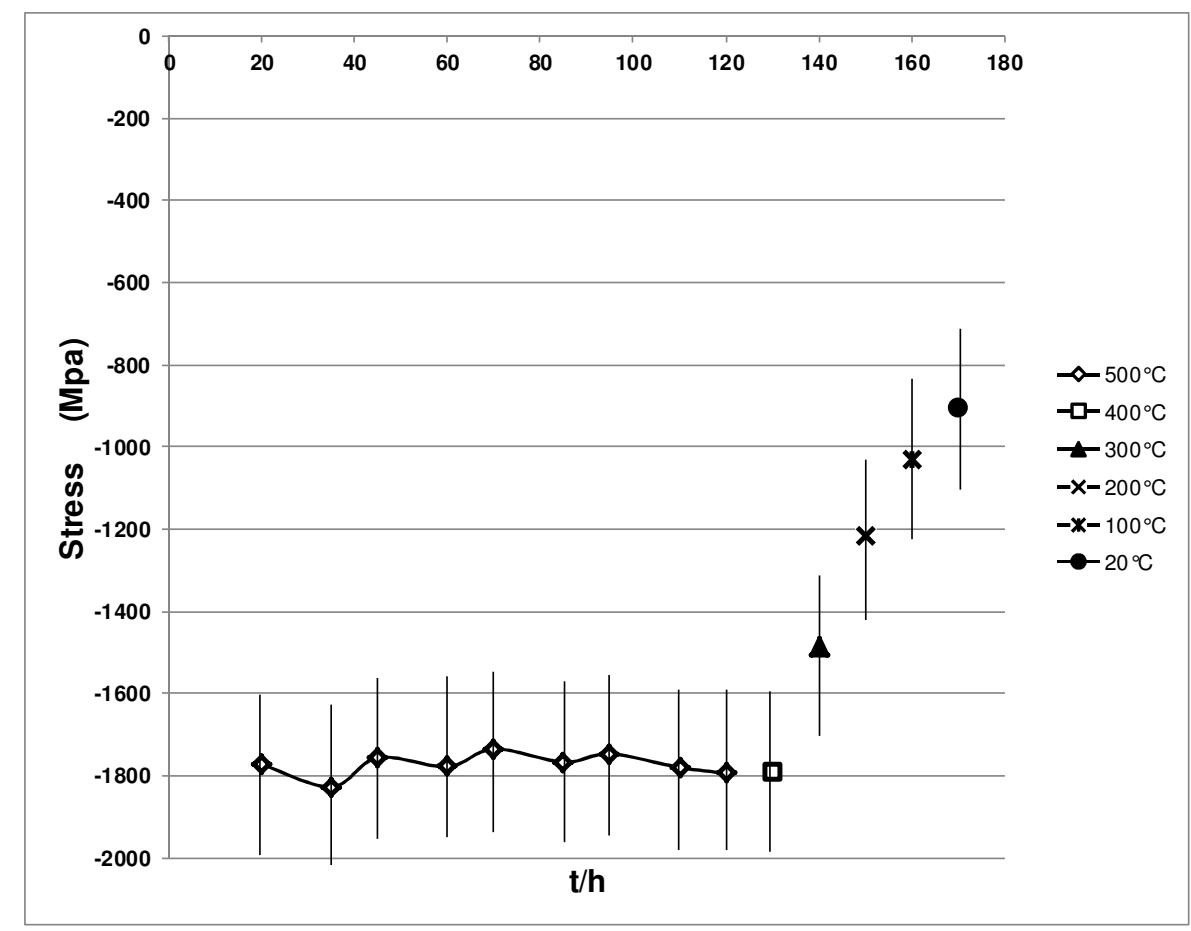

Figure 1. In situ growth stress determination in the $\mathrm{m}-\mathrm{ZrO}_{2}$ scale in dry air at $500{ }^{\circ} \mathrm{C}$ and during cooling to room temperature.

3.4. Determination of the stress evolution in the $\mathrm{m}-\mathrm{ZrO}_{2}$ scale at $500{ }^{\circ} \mathrm{C}$ and during cooling to room temperature in wet air $\left(15\right.$ vol. $\left.\% \mathrm{H}_{2} \mathrm{O}\right)$.

Figure 2 shows the in situ growth stress determination in the $\mathrm{m}-\mathrm{ZrO}_{2}$ oxide scale in wet air (15 vol. $\% \mathrm{H}_{2} \mathrm{O}$ ) at $500{ }^{\circ} \mathrm{C}$ and during cooling to room temperature. After 40 hours oxidation the stress determination is possible in the $\mathrm{m}-\mathrm{ZrO}_{2}$ scale and the growth stress close to $(-1700+/-200 \mathrm{MPa})$. Compressive stress decreases after the initial stage oxidation to reach a value close to $(-1000+/-200$ $\mathrm{MPa}$ ). Then, it remains constant along the oxidation test. On the specimen surface exposed to wet air the oxide scale is about $2 \mu \mathrm{m}$ thick. The scale is finer than the one obtained in dry air. Nevertheless, results show that the compressive growth stress registered in the oxide scale is lower in wet air compared to dry air environment. At $400{ }^{\circ} \mathrm{C}$ and for lower temperatures the compressive stress remains close to $-1000+/-200 \mathrm{MPa}$. This indicates that thermal stresses are not relaxed during cooling by crack formation or creep due to the specific mechanical properties of the oxide induced by the presence of water in air. It should also be noticed that the residual stress values obtained after cooling to room temperature in dry and wet air are close to each other $(-1000+/-200 \mathrm{MPa})$. This is due to the stress decrease after dry air oxidation and stress value remaining constant after wet air oxidation. Nevertheless, in situ growth stress determinations have shown that the compressive stress is much higher in dry air oxidation conditions at $500{ }^{\circ} \mathrm{C}$. 


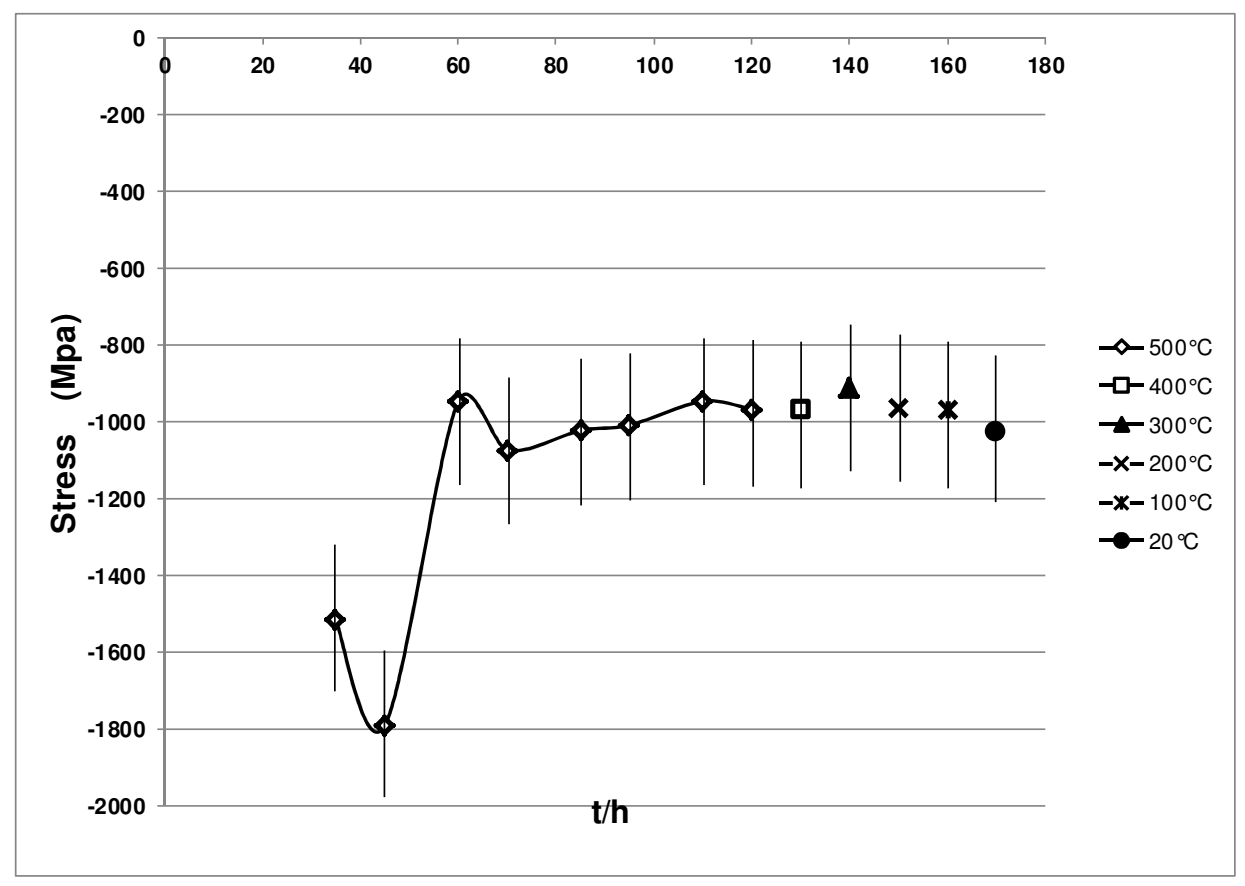

Figure 2.In situ growth stress determination in the $\mathrm{m}-\mathrm{ZrO}_{2}$ oxide scale in wet air $\left(15 \mathrm{vol} . \% \mathrm{H}_{2} \mathrm{O}\right)$ at $500{ }^{\circ} \mathrm{C}$ and during cooling to room temperature.

\section{DISCUSSION}

In dry air, the present results show that the $(-1800+/-200 \mathrm{MPa})$ compressive growth stress in the oxide is close to the average residual stress magnitude found in the oxide scale formed at $500^{\circ} \mathrm{C}$ on $\mathrm{Zr}$ and other alloys (M5, Zy-2) [26, 27]. In the literature it is shown that the stress magnitude reaches a maximum value for a scale thickness ranging between 4 and $6 \mu \mathrm{m}$ on M5 at $550{ }^{\circ} \mathrm{C}$ [28]. In our study the growth stress determined by XRD remains constant all along the $120 \mathrm{~h}$ isothermal test because the scale thickness remains below $6 \mu \mathrm{m}$ and the analytical technique gives a mean stress value for the whole oxide scale. In situ growth stress determination in the oxide scale indicates that the compressive stress is larger in dry air compared to wet air environment at $500{ }^{\circ} \mathrm{C}(-1000+/-200 \mathrm{MPa})$. The lower stress state observed in wet environment is in accordance with the results of Pétigny [10, 11]. A comparative study on the effect of oxygen and steam was performed by this author at $470^{\circ} \mathrm{C}$ by using $\mathrm{X}$-ray diffraction. It appears that the average stress magnitudes are larger for oxygen compared to steam. These results are consistent with the values obtained by synchrotron X-ray diffraction by Béchade et al. at $400^{\circ} \mathrm{C}[29,30]$. As observed in the present work, it has been proposed that under wet atmospheres, the average stress values are at a maximum at the very early oxidation stage and then decreases. This behaviour may be related to stress relaxation phenomena taking place early during the formation of the scale [21]. This could explain the relatively low stress values obtained in wet air in the present work even though the stress determination could not be performed at the very beginning of the test (before 40 hours) due to the too low scale thickness. In dry air, the compressive growth stress registered in the $\mathrm{m}-\mathrm{ZrO}_{2}$ scale at $500{ }^{\circ} \mathrm{C}$ is relatively high $(-1800+/-200 \mathrm{MPa})$ (Figure 1). At $300{ }^{\circ} \mathrm{C}$ 
and at lower temperatures the compressive stress decreases to reach $-900+/-200 \mathrm{MPa}$ at room temperature. The progressive stress decrease indicates that a relaxation process occurred during cooling due to cracks initiation and propagation in the zirconia scale during cooling. In wet air, the compressive growth stress registered at $500{ }^{\circ} \mathrm{C}$ is relatively low $(-1000+/-200 \mathrm{MPa})$ in the $\mathrm{m}-\mathrm{ZrO}_{2}$ scale (Figure 2). At $400{ }^{\circ} \mathrm{C}$ and for lower temperatures the compressive stress remains the same $(-1000+/-200 \mathrm{MPa})$. It indicates that thermal stresses are not relaxed during cooling by crack formation or creep due to the specific mechanical properties of the oxide induced by the presence of water in air. It has been observed that the residual stress values obtained after cooling to room temperature in dry and wet air are close to each other $(-1000+/-200 \mathrm{MPa})$. This is due to the stress relaxation after dry air oxidation and the constant stress value registered after wet air oxidation. This indicates that no important stress relaxation by scale cracking occurred in zirconia scales obtained under wet air conditions during cooling, because cracking has already occurred under isothermal conditions after the early stage oxidation period (about 60 hours). It has also been proposed that the incorporation of hydrogen can occur in the metal in the presence of steam [30]. Hydrogen is located in interstitial positions in the $\mathrm{Zr}$ hexagonal lattice; or if the solubility limit is exceeded, it forms $\mathrm{Zr}$ hydride precipitates. In both cases it leads to an increase of the volume of the metal which may modify the stress evolution [31, 32]. However, a comparison of the results obtained under dry and wet conditions show that no detectable influence of hydrogen has been registered in the mean stress state of the alloy even if hydrogen dissolution is expected during wet air oxidation.

\section{CONCLUSION}

In situ growth stress determination in the oxide scale has shown that the compressive stress is larger in dry air oxidation conditions compared to wet air environment at $500{ }^{\circ} \mathrm{C}$. The lower stress state observed in wet environment is in accordance with results performed in the same temperature range on other zirconium alloys. The lower growth stress can be explained by growth stress relaxation due to cracking of the oxide in wet air at $500{ }^{\circ} \mathrm{C}$. This will be confirmed by acoustic emission experiments. The oxide creep can also be favoured in wet air due to proton doping of zirconia or hydrogen diffusion in the alloy. Analysis of the hydrogen content after wet air oxidation will be performed in the near future. After dry air oxidation, the compressive stress decreased during cooling from $-1800+/-200$ $\mathrm{MPa}$ to reach $-900+/-200 \mathrm{MPa}$ at room temperature. It indicates that a relaxation process occurred during cooling due to cracks initiation and propagation in the zirconia scale. After wet air oxidation, the compressive stress remains close to $-1000+/-200 \mathrm{MPa}$ even after cooling to room temperature. This indicates that the growth stress state in the oxide scale is not high enough to induce detectable stress relaxation during cooling due to the specific mechanical properties of the oxide induced by the presence of water in air.

Acknowledgement. The DENOPI project is a work performed in the frame of the DENOPI project, funded by the French government as part of the "Investment for the Future" Program reference ANR11-RSNR-0006.

\section{REFERENCES}

[1] S. Chevalier, J. Favergeon, French Activity on High Temperature Corrosion in water Vapour, Materials Science Foundation, Vol. 36, Chapter 4,Trans Tech Publications, Zürich, 201376 (2013) 77-122. 
[2] J. Godlewski, ASTM STP 1245 (1994)663-683

[3] S. Leistikow, G. Schanz, Nucl. Eng. Des. 103 (1987) 65-84.

[4] M. Steinbrück, Oxid. Met. 70 (2008) 317.

[5] B. Cox, J. Nucl. Mater. 148 (3) (1987) 332-343.

[6] C. Duriez, T. Dupont, B. Schmet, F. Enoch, J. Nucl. Mater. 380 (2008) 30-45.

[7] M. Parise, O. Sicardy, G. Cailletaud, J. Nucl. Mater. 256 (1998) 35-46.

[8] J.P. Pemsler, Electro-chem. Technol. 4 (128) (1966).

[9] A.J.G. Maroto, R. Bordoni, M. Villegas, A.M. Olmedo, M.A. Blesa, A. Iglesias, P.Koenig, , J.Nucl. Mater. 229 (1996) 79-92.

[10] N. Pétigny-Putigny, , Ph.D.Thesis, Université de Bourgogne, France, 1998.

[11] N. Pétigny-Putigny, P. Barberis, C. Lemaignan, Ch. Valot, M. Lallemant, J. Nucl. Mater. 280 (2000) 318-330.

[12] A. Yilmazbayhan, A.T. Motta, R.J. Comstock, G.P. Sabol, B. Lai, Z. Cai, J. Nucl. Mater. 324(1) (2004) 6-22.

[13] E. Polatidis, P. Frankel, J. Wei, M. Klaus, R.J. Comstock, A. Ambard, S. Lyon, R.A.Cottis, M. Preuss, J. Nucl. Mater. 432 (1-3) (2013) 102-112.

[14] J. Godlewski, J. Gros, M. Lambertin, J. Wadier, H. Weidinger, ASTM STP 1132 (1991) 416436.

[15] I. Idarraga-Trujillo,Ph.D. Thesis, Université de Grenoble, France, 2011.

[16] H. El Kadiri, Z.N. Utegulov, M. Khafizov, M. Asle Zaeem, M. Mamivand, L.Oppedal, K. Enakoutsa, M. Cherkaoui, R.H. Graham, A. Arockiasamy,Acta Mater. 61 (11) (2013) 39233935.

[17] I. Idarraga, M. Mermoux, C. Duriez, A. Crisci, J.P. Mardon, Oxid. Met. 79 (2013) 289-302.

[18] H. Anada, K. Takeda, ASTM Spec. Tech. Publ.1295 (1996) 35-54.

[19] A. Yilmazbayhan, E. Breval, A.T. Motta, R.J. Comstock, J. Nucl. Mater.349 (3) (2006) 265-281.

[20] W. Qin, C. Nam, H.L. Li, J.A. Szpunar, Acta Mater.55 (2006) 1695-1701.

[21] M. Guerain, C. Duriez, J.L. Grosseau-Poussard, M . Mermoux, Corros. Sci. 95 (2015) 11-21.

[22] S. Chevalier, J. Favergeon, French Activity on High Temperature Corrosion in water Vapour, Materials Science Foundation, Vol. 36, Chapter 5,Trans Tech Publications, Zürich, 201376 (2013) 77-122.

[23] Chun. Liu, Thèse de Doctorat, ENSAM Paris (1991).

[24] F. Bernard, E. Sciora, N. Gerard, J. Phys. IV C4 (6) (1996) 259-266.

[25] C. Valot, Ph.D. Thesis, Université de Bourgogne, France, 1995.

[26] C. Roy, G. David, J. Nucl. Mater. 37 (1970) 71-81.

[27] C. Roy, B. Burgess, Oxid. Met. 2 (1970) 235-261.

[28] B. Panicaud, J.L. Grosseau-Poussard, D. Retraint, M. Guerain, L. Li, Corros. Sci. 68 (2012) 263274.

[29] J.L. Béchade, P. Goudeau, M. Gailhanou, P. Yvon, High Temp. Mater. Processes 2 (3) (1998) 59-67.

[30] S.J. King, R.L. Kesterson, K.H. Yueh, R.J. Comstock, W.M. Herwig, S.D. Ferguson, ASTMP STP 1423 (2002) 471-489.

[31] B. Krebs, J. Desquines, V. Busser, D. Drouan, O. Zanellato, J. Nucl.Mater. 435 (2013) 41-48.

[32] P. Barberis, V. Rebeyrolle, J.J. Vermoyal, V. Chabretou, J.P. Vassault, ASTM STP 1505 (2009) 612-630. 